\title{
Error Analysis in the Foreign Language Classroom (VIII Grade)
}

\author{
Julija Jaramaz, MA \\ University of Montenegro, Faculty of Philosophy, Nikšić \\ Department of English Language and Literature
}

\section{Doi:10.5901/mjss.2014.v5n13p147}

\begin{abstract}
Generally, learning English language for primary school children represents a problem. Many errors are produced as a result, including some which we will deal with in the research part of this work. This work deals with analysis of some grammatical and lexical errors in learning English language at primary school level. Research has been conducted (pupils in the VIII grade of elementary school from the central, southern and northern parts of Montenegro) within which we want to examine if there are any regional differences coming out of qualitative and quantitative error analysis and which are the most common errors for pupils of this level of schooling. The aim is to obtain results which might help our educational authorities with determing which aspects to pay special attention to when designing test and putting together programmes for elementary school children. These results can also help our teachers to know which grammatical and lexical aspects are the most difficult for them, and to focus their attention on how to teach them.
\end{abstract}

Keywords: grammatical and lexical errors, difficult items, percentage estimated results

\section{Introduction}

Most people think that errors are part of learning. Most people also think that correcting errors is part of teaching. If making errors is part of learning, and correcting them part of teaching, there is an interesting question: how can these two go together?

We learn how to swim, first by jumping into the water, moving our legs and hands aimlessly, until such time as we become aware that there is a structural combination of moves which makes us able to stay on the surface of the water and to swim over it. Our first mistakes during swimming are big one, but they start to be smaller and smaller. We learn how to swim during the process of making mistakes. (Brown, H. D. 1994: 204). It is the same situation with learning a foreign language. At the very beginning we make a lot of mistakes, but later, they become less and appear only from time to time, and finally we can say that we have learned a language.

\subsection{Mistakes or errors}

The first step in the methodological research of errors is to defining the term 'error'. This means that we first need to make a difference between the terms 'mistake' and 'error'. A mistake is an occasional error, but a real error is an error made because of insufficient knowledge. It's not always simple to differentiate between a mistake and an error. If a pupil says on one occasion: "Anne cans sing", and another time: "Anne can swim", we cannot be sure if it is a mistake or an error. If the pupil always uses the construction "Anne mays go", or "Anne cans do something", we are sure that he or she is making an error, not a mistake. It means that that pupil does not know the rule for making modal verbs (without an ' $s$ ' in the third person singular). The conclusion is, that if the pupil cannot notice that he is making a mistake on his own, and does it again, it is an error, but if he makes a mistake, and immediately corrects himself, that is a mistake.

The fact that pupils often make errors forces us to research them, to classify and analyze them. This is known as error analysis. When we say error analysis, our first association is that it is something negative, but we have to be aware of the fact that making the mistakes can be something positive which means that in that way we can know what is unfamiliar to our pupils, and the teacher's job, in that case, is to try to teach them and correct their errors in the best possible way (with appropriate strategy or technique).

It is evident that when we talk about error analysis in the process of teaching, there is always a possibility of paying too much attention to correcting them. Primary school children are very motivated about learning a foreign language and during their speaking or writing they do not mind the quantity of errors they make. They are more focused on the summary of the text or on communication fluency than on answering the question how many errors they make, and which kind. The teachers should be aware of how many errors they correct and they should not allow fear of making mistakes to overwhelm their enthusiasm for learning. They should know that fluency is very important. We should never forget that 
the main aim of learning a foreign language is the capability of free communication, whether we are talking about written or spoken expression.

\subsection{Identification and description of an error}

The first step in the process of error analysis is its identification and description. According to Lennon Sharron (1989: 69), we can divide errors into the following categories:

1) Errors made by the process of addition (Does he can sing?), where we have added the auxiliary word 'does' to the modal sentence.

2) Errors made by the process of supposition (I went to movie, instead of I went to the movie - definite article)

3) Errors made by incorrect word order (I to the movie went).

There is also the classification of errors into global and local. Global errors 'hide' the communication, they keep the listener from hearing some of the main aspects of the message. For example, we have the sentence Well, it's great to hurry around, and it can be difficult or almost impossible to interpret it just because of this confused chain of words. Local errors do not make it impossible for us to hear the right message of its meaning, because there is only a minor violation of one segment of the sentence, and it makes it possible for us to guess the right meaning of it (for example, when we put the indefinite article a next to the plural of a noun)1.

Finally, (Lennon 1989) suggests two dimensions of errors: area and extensive types of errors. Area errors include some language items (from phoneme to discourse), which should be seen within its context if we want to notice that there is an error, and extensive errors represent a connection of language items in which we should erase, move or add something if we want to correct a sentence. If we take a look at the previous example (a scissors), an area error would be the phrase itself, and an extensive error would be the indefinite article.

Edge (1989: 69) thinks that there is a classification of errors into:

a) Grammar - She told she was on holiday. In this sentence it is necessary to add a noun or pronoun, for example : She told him she was on holiday;

b) Lexical - I've lost my ruler, can I lend yours? In this sentence it is necessary to put borrow instead of lend.

c) Word order errors (syntactical errors)

Where Peter is today? (Where is Peter today?).

Of course, if we want to be more precise, we can classify errors in the next way: wrong verb tense, for example if we do not use the present perfect where it is necessary: (He just came, instead of He has just come), prepositional errors, which means wrong usage of preposition: at Saturday, instead of on Saturday; wrong usage of articles, for example: a scissors, where we have the article a in front of the plural noun.

Errors which appear during the process of learning, especially in grammar, are the main part of acquiring the language, but the types of errors that are the most typical because of their difficulties, are grammatical and lexical, and because of that, we need to pay special attention to them.

"Learning from one's mistakes is not just a proverb, but the main part of all methods in the process of learning a foreign language. Making mistakes is inevitable during that long process." (Čarapić, 2012: 191) This refers mainly to grammar because this represents the main problem in the process of learning a foreign language, which causes a lot of grammatical errors.

\subsubsection{Grammatical errors}

Learning English grammar, just as with learning any other language, can be a big problem. The problem can be not only in the way it is presented. Every experienced teacher is faced with the fact that the best way of presenting grammar is not to count on the fact that the things which are presented in the classroom will be memorised after entering it. There is something in learning a foreign language that changes the most common rules about learning the language, and that is the fact that our brain has built a system of how to learn something (Scovel, 1998: 43). It is not only the experience of teachers who work with the pupils, but scientists also claim that, whichever kind of method a teacher uses for teaching grammar, sometimes it is in vain, because the process of learning is not just a mechanical, linear input-output process, but rather the way of acquiring knowledge is more complex. (Scott Thornbury, 2001: 37)

It is very interesting to notice that Thornbury in his research concluded that pupils sometimes make errors more often with some easier grammar constructions, than with difficult ones. For example, pupils make errors in the simple

${ }^{1}$ A scissors 
present tense (going instead of go), then they have difficulties with some prepositions (at the night, at the morning...); but on the other hand they correctly use some constructions in the simple past tense based on recognizing verb tenses according to the places of adverbs of time (yesterday, a week ago). This can be explained in the words of Carl Schmidt, who says that we sometimes need more time to learn some things, and our consciousness and subconsciousness are included here (Scott Thornbury, 2001: 38), and that is the reason why explaining some grammatical dilemmas to the pupils is sometimes unavoidable. Their brain needs to 'find the key' to solving the problem.

On the other hand, researching the errors which elementary school children make, Naum Dimitrijević (1966: 124) concludes that in grammar, the smallest error can cause misunderstanding, can convey incorrect information or lead to an incorrect understanding of the text. It is very important, for example, to notice if the pupil says book or books, because it is not the same. It is also not the same to say "He eats what he sees" or "He sees what he eats" (Scott Thornbury, 2001: 38), although we are talking about only one word. Dimitrijević (1966) also says that there is a big problem with the interrogative and negative forms of the simple present tense and present continuous tense. He concludes in his research that the double possibility of making the present tense form with the auxiliary verb do, with the -es form in the third person singular form, is the problem. We notice in our research that pupils do not use the form does (he/she/it does) in the third person singular form, and also they do not put an -s on the end of the verb for the third person singular (He work instead He works).

Because of the fact that, except for grammatical errors, lexical errors are the most dominant ones, we should pay attention to this kind of error, too.

\subsubsection{Lexical errors}

According to empirical research by Maer (1984), we can say that lexical errors are maybe the most dominant of all in pupils' speech, and because of that we should pay special attention to them. Because of the fact that an inadequate choice of words (lexical choice of words) can cause a misunderstanding of the context, lexical error analysis can be crucial.

Duskova (1969) mentions four types of lexical errors. She talks about errors in style (formal/informal), then a wrong choice of words (similarities between the mother tongue and foreign language), errors caused by similarity in meaning (trip/journey), errors made by the change of words (solve/dissolve) (Čarapić, D. 2012: 191). It means that lexical errors can be caused by influence of the mother tongue, and in this case we can talk about language interference (Laufer, 1997).

James (1998: 192), classifies lexical errors into formal and semantic errors. Formal errors are: wrong usage of the word form ${ }^{2}$, errors in the word form ${ }^{3}$, word modification ${ }^{4}$. Semantic errors are errors according to relations in the meaning ${ }^{5}$ and errors in the choice of collocations ${ }^{6}$.

Čarapić (2012: 192) says that a high level of language knowledge does not mean a lower number of lexical errors. On the contrary, sometimes pupils on a higher level (grade), make more errors than those in lower levels.

On the basis of this, in the next chapter we will talk about research made in a higher grade (VIII) in order to see their knowledge of grammar and lexis.

\section{Corpus and Methodology}

This work is based on corpus of recorded English language classes of elementary school children. It is of a regional character which means that we recorded classes of eighth grade pupils from the central, northern and southern parts of

\footnotetext{
2 Suffix type (considerable/considerate); prefix type (reserve/preserve); type based on vowels (manual/menial; type based on consonants (save/safe) (Čarapić, D. 1998: 193).

${ }^{3}$ Calques which appear as the result of interference from the mother tongue (economical situation leconomic situation) (Čarapić, $D$. 1998: 193).

4 Omission of grapheme (intersing/interesting); unnecessary addition of grapheme (dinning room/dining room); error in letter order (littel/little) etc. (Čarapić, D. 1998: 193).

5 Usage of superonym instead of hyponym (We have modern equipment in our house/appliances); usage of hyponym instead superonym (The colonels/officers live in the castle); usage of the appropriate co-hyponym (I think the city has good communication/public transport such as a lot of buses); usage of the wrong similar synonym ( regretful/penitent). (Čarapić, D. 1998: 193).

${ }^{6}$ Semantical wrong choice of words (The city is grown/developed); syntactically wrong choice of words (An army has suffered big losses/heavy losses); (Čarapić, D. 1998: 193).
} 
Montenegro. More precisely we included the following elementary schools, Olga Golović in Nikšič (three recorded classes), Njegoš in Kotor (three recorded classes) and Vukašin Radunović in Berane (three recorded classes). After recording classes, we made a transcription of them.

In reference to methodology, we chose comparative analysis to check whether there was a large difference in the number and type of errors which pupils made at this level.

We also chose the method of contrastive analysis, by which we wanted to notice if there was a variation in errors depending on the part of Montenegro the pupils come from, and one of our aims was to spot these variations, if there were any, and also the possible reasons for this.

As a model for classification in this case, we used the chart (chart 1) Common Mistakes in English by the author T.J. Fitikides, because it is very clear, precise and concise, and it offered us a very simple view of all errors which appear in pupils' speech. This kind of error review gives us the possibility to more easily spot them, and then to classify them, and after that to compare the errors (grammatical and lexical), and calculate their percentage in the end.

\subsection{Results}

After classifying the errors into grammatical and lexical, in our next chapter we will give a review of the common errors and their frequency in pupils' speech. Errors are numerically marked and in this way it is evident to which category they belong to.

Chart 1: the number of errors with their frequency

\begin{tabular}{|l|c|c|c|}
\hline Mistakes & $\begin{array}{c}\text { "Olga Golović" } \\
\text { Elementary School, Nikšić }\end{array}$ & $\begin{array}{c}\text { "Njegoš" Elementary } \\
\text { School, Kotor }\end{array}$ & $\begin{array}{c}\text { "Vukašin Radunović" } \\
\text { Elementary school, Berane }\end{array}$ \\
\hline I Missused Forms & & & 1 \\
\hline Using a Wrong Preposition & 1 & & 11 \\
\hline Misuse of the Infinitive & & & \\
\hline The Use of a Wrong Tense & & & \\
\hline Miscellaneous Examles & & & \\
\hline Un-English Expressions & & & \\
\hline III IncorrectOmissions & & & \\
\hline Omission of Prepositions, Verbs... & & & \\
\hline Miscellaneous Examples & & & \\
\hline III Unnecessary Words & & & \\
\hline Unnecessary Prepositions & & & \\
\hline Unnecessary Articles & & & \\
\hline The Infinitive without "To" & & & \\
\hline Miscellaneous Examples & & & \\
\hline IV Misplaced Words & & & \\
\hline Wrong Position of Adverbs & & & \\
\hline V Confused Words & & & \\
\hline Prepositions often Confused & & & \\
\hline Verbs often Confused & & & \\
\hline Adverbs often Confused & & & \\
\hline Adjectives often Confused & & & \\
\hline Nouns often Confused & & & \\
\hline Confusion of Number & & & \\
\hline Confusion of Parts of Speech & & & \\
\hline VI Have another look at: & & & \\
\hline The Use of the Gerund & & & \\
\hline The Use of Certain Tenses & & & \\
\hline Negatives & & & \\
\hline The Third Person Singular & & & \\
\hline The Indefinite Article & & & \\
\hline The Verb "To Be" & & & \\
\hline
\end{tabular}

${ }^{7}$ In this chart it is written mistakes not errors because in that time (1968), there was not a clear difference between these two terms. 


\begin{tabular}{|l|c|c|c|}
\hline Mistakes & $\begin{array}{c}\text { "Olga Golović“ } \\
\text { Elementary School, Nikšić }\end{array}$ & $\begin{array}{c}\text { "Njegoš“ Elementary } \\
\text { School, Kotor }\end{array}$ & $\begin{array}{c}\text { "Vukašin Radunović" } \\
\text { Elementary school, Berane }\end{array}$ \\
\hline The Definite Article & & & \\
\hline Questions & & & \\
\hline The Correct Order of Word & 1 & & \\
\hline Singular and Plural & 1 & 1 & 15 \\
\hline Ukupno & 7 & 9 & \\
\hline
\end{tabular}

Chart 2: grammatical and lexical errors noted in the pupils' speech

\begin{tabular}{|c|c|c|}
\hline Grade VIII & Grammatical errors & Lexical errors \\
\hline $\begin{array}{c}\text { „Olga Golović“" Elementary } \\
\text { School, Nikšić }\end{array}$ & $\begin{array}{l}\text { 1.I take/l'm taking } \\
\text { 2.I goll'm going } \\
\text { 3.animals lives there/live } \\
\text { 4.only_phone/the } \\
\text { 5. Here comes my friend Igor/ My friend lgor comes here } \\
\text { 6. When_is cold/it }\end{array}$ & 1.depend of/depend on \\
\hline $\begin{array}{c}\text { „Njegoš“ Elementary School, } \\
\text { Kotor }\end{array}$ & $\begin{array}{l}\text { 7.was madelis made } \\
\text { 8.if it's not good, l'didn't/l don't } \\
\text { 9. a group were silent/was }\end{array}$ & $\begin{array}{l}\text { 2.like ten minutes/about } \\
\text { 3.to appoint friends/meet } \\
\text { 4.to draw/underline } \\
\text { 5.smart knowledge/good } \\
\text { 6.still music/quiet } \\
\text { 7.My mother draws me/pulls }\end{array}$ \\
\hline $\begin{array}{c}\text { „Vukašin Radunović“" Elementar } \\
\text { school, Berane }\end{array}$ & $\begin{array}{l}\text { 10.where did you go?-I go.../I went } \\
\text { 11.What did you see?I see.../l saw } \\
\text { 12.have you ever talk/talked } \\
\text { 13.have you ever get/got } \\
\text { 14.have you ever cook/cooked } \\
\text { 15.why did you felt/feel } \\
\text { 16.what did you lost/lose } \\
\text { 17.what did you got/get } \\
\text { 18.have ever you seen/have you ever seen } \\
\text { 19.what did you bought/buy } \\
\text { 20.he have/has } \\
\text { 21.who win/who won } \\
\text { 22.where has that been/where was that... } \\
\text { 23.a animal/an }\end{array}$ & 8.look in that/look at that \\
\hline Total & 23 & 8 \\
\hline
\end{tabular}

According to the analysis we can conclude that at the level of VIII grade elementary school children we have 31 errors by which 15 of them relate to bad knowledge of verb tenses. This result shows that $48.38 \%$ of errors refer to bad knowledge of the previously mentioned category.

Classifying errors as grammatical or lexical, we notice that there are more grammatical ones (23) than lexical ones (eight). The percentage results show that $74.19 \%$ are grammatical errors.

Trying to see if there are larger variations in classification of errors depending on the part of Montenegro the pupils come from, we have the following results:

For the central part of Montenegro (Olga Golović Elementary School, Nikšić), our analysis shows that there are seven errors (six grammatical and one lexical), which is $85.71 \%$ grammatical errors.

In the south of Montenegro (Njegoš Elementary School, Kotor), analysis shows that by the total number of errors (three grammatical and six lexical), $66.66 \%$ are lexical ones, which means that we have more lexical than grammatical errors here.

According to the research of the northern part of Montenegro (Vukašin Radunović Elementary School, Berane), the analysis shows that by the total number of errors (14 grammatical and one lexical), grammatical ones are the most common. In percentage term $93.33 \%$ are grammatical errors.

These results show that there are some variations in making errors according to the part of Montenegro the pupils come from, but they are not so large. In two schools we have a predominance of grammatical errors, but in one we have more lexical errors. 
According to the fact that one of our aims was to see if there were some large variations in error classification depending on which part of Montenegro the pupils came from, our analysis showed the following:

For the central part of Montenegro (Olga Golović Elementary School, Nikšić), the analysis shows that out of seven errors, two of them refer to bad knowledge of verb tenses, but also two of them refer to omission of prepositions, verbs and articles. In percentage terms, this is $28.57 \%$ of all errors. The other errors are less common, there being only one of them.

For the southern part of Montenegro (Njegoš Elementary School, Kotor), our analysis shows that out of all the errors (nine), three of them, or $33.33 \%$ refer to inadequate usage of a verb (lexical), and the other errors are not so representative.

According to the research referring to the northern part of Montenegro (Vukašin Radunović Elementary School, Berane), the results show that out of all the errors (15), 11 of them refer to bad knowledge of verb tenses, which means $73.33 \%$ of all errors. Interference of the mother tongue is present here. ${ }^{8}$

The results of this research show that there are some exceptions when referring to the type of grammatical and lexical errors depending on which part of Montenegro the pupils come from.

The percentage results of grammatical and lexical errors of the VIII grade pupils can be seen here:

Chart 3: Grammatical vs. lexical errors

\begin{tabular}{|c|c|}
\hline Grammatical errors & $74.19 \%$ \\
\hline Lexical errors & $25.81 \%$ \\
\hline
\end{tabular}

As one of our aims was to see if verb tenses were the most common category of grammatical errors, according to Chart 3 , it is evident that this category is the most difficult for our pupils. In percentage terms this is $43.38 \%$.

\section{Chart 4}

\section{Grammatical errors (verb tenses)} $48.38 \%$

After percentage data processing of the central, south and north part of Montenegro, with the aim of establishing whether there are any differences in classification and scope depending on the region of Montenegro, it is clear that grammatical errors are more present in the central and northern parts, and lexical ones are more dominant in the southern part of Montenegro.

The chart can be seen here:

\section{Chart 5}

\begin{tabular}{|c|c|c|c|c|}
\hline Nikšić & Grammatical errors & \multirow{2}{*}{$85.71 \%$} & Verb tenses and omission of articles, verbs, etc. & $28.57 \%$ \\
$28.57 \%$ \\
\hline Kotor & Lexical errors & $66.66 \%$ & Inadequate usage of verb & $33.33 \%$ \\
\hline Berane & Grammatical errors & $93.33 \%$ & Verb tenses & $73.33 \%$ \\
\hline
\end{tabular}

\section{Conclusion}

In this work we have dealt with grammatical and lexical error analysis in spoken discourse in the English language classroom. Analysis of errors, their frequency and systematic research about their categories (grammatical and lexical), on one hand offer us a clear view about the language learning difficulties, but on the other hand show us that making errors can be very important in the process of acquiring knowledge, by viewing the possible error categories.

Trying to see if there are larger variations in the classification of errors depending on the part of Montenegro the pupils come from, we have the following results:

For the central part of Montenegro, grammatical errors are dominant (verb tenses, omissions of prepositions, verbs etc). In the south of Montenegro lexical errors appear as more dominant (inadequate usage of verbs lend/borrow). According to the research, in the northern part of Montenegro grammatical errors are the most common ones (verb 
tenses).

Because teaching is a very complex activity depending on many factors - objective and subjective, external and internal - we suppose that this work, in a some way, will make a contribution to understanding the complexities of teaching foreign languages, in this case the English language. It particularly relates to a methodological approach to these or similar problems, but also the obtained results of the research can be used as the basis for further research, and also for concrete action in school practice.

\section{References}

Anderson, T. (1969): Foreign Languages in the Elementary School, University of Texas, Press Austria and London.

Brown, H.D. (1987): Principles of Language Learning and Teaching, Prentice-Hall, Englewood Clifts, N. J., 2nd edition.

Brown, G. and Yule,G. (1983): Discourse Analysis, Cambridge: Cambridge University Press.

Corder, S. P. (1967): The significance of learner's errors, International Journal of Applied Linguistics, Oxford, 1967.

Čarapić, D. (2012): Analiza leksičkih grešaka u esejima studenata, Zbornik radova sa druge Konferencije društva za primijenjenu lingvistiku, Urednik: Prof. dr Slavica Perović, Podgorica, Društvo za primijenjenu lingvistiku Crne Gore.

Dimitrijević, N. (1966): Metod u početnoj nastavi stranog jezika, Zavod za izdavanje udžbenika, Beograd.

Duskova, L. (1969): On sources of errors in foreign language learning, International Review of Applied Linguistics.

Edge, J. (1989): Mistakes and Correction, by Longman Publishing, London and New York.

Fitikides, T.J. (1969): Common Mistakes in English, Longman.

Harmer, J. (1999): How to Teach Grammar, Printed in Spain by Mateu Cromo.

Krashen, S. and Terrell, T. D. (1983): The Natural Approach, Pergamon Press, San Francisco.

Krashen, S. (1982): Principles and practice in second language acquisition, Oxford, Pergamon.

James, C. (1998): Errors in language learning and use: Exploring error analysis, New York: Longman.

Laufer, B. (1977): What's in a word that makes it hard or easy: Some intralexical factors that affect the learning of words, u N. Schmitt \& M. McCarthy (eds.) Vocabulary: Description, Acquisition and Pedagogy, Cambridge: Cambridge University Press.

Lennon, S., (1989): Error: some problem of definition, identification and distinction,"Applied Linguistics", XII/2.

Maera, P. (1984): The study of lexis in interlanguage, u A. Davies, C. Criper \& A. Howatt (Eds.) Interlanguage, Edimburgh: Edimburgh University Press.

Nunan, D. (1998): Teaching Grammar in context, ELT Journal Volume 52/2, Oxford University Press.

Richards, J. C. (1974): Error analysis, Perspectives on Second Language Acqusition, Longman, London.

Scovel, T. (1998): Psycholinguistics, London, Oxford University Press.

Scrivener, J. (1994): Learning Teaching, Printed in Great Britain by Bath Press.

Thornbury, S. (2001): Uncovering Grammar, Great Britain: Scotprint.

Thornbury, S. (1999): How to Teach Grammar, Longman. 